\title{
Comparison of Labor Costs between Floridian and Mexican Strawberry Industries ${ }^{1}$
}

\author{
Feng Wu, Zhengfei Guan, and Melvin Garcia-Nazariega ${ }^{2}$
}

\section{Introduction}

Florida has the largest winter strawberry production in the United States. In 2016, the Florida strawberry industry planted 11,000 acres of strawberries and produced 240 million pounds strawberries (USDA-NASS 2016). The farm gate value of the industry was $\$ 291$ million in 2016, and the total economic contribution of the industry was estimated at over $\$ 700$ million in 2015 (personal communications, A. Hodges 2017). In recent years, Florida's industry has faced growing competition from Mexico. Fresh strawberry imports from Mexico grew dramatically in the 2004-2014 period, with total imports to the United States increasing fourfold, from 93 million pounds to 355 million pounds. Total US strawberry imports reached a record 365 million pounds in 2016 (USDA-NASS 2016), almost exclusively from Mexico (99.7\%). Most of the Mexican strawberries are produced in Central Mexico and are imported in wintertime when Florida strawberries are on the market, which poses a great challenge to the Florida strawberry industry (Suh, Guan, Khachatryan 2017).

Mexico's major competitive advantage is cheaper labor costs (Biswas, Guan, and Wu 2017). Strawberry is a laborintensive crop that requires a significant amount of labor. In Florida, labor is the largest cost item in the strawberry production budget, accounting for almost $40 \%$ of total production costs (Guan, Wu, and Whidden 2017). The

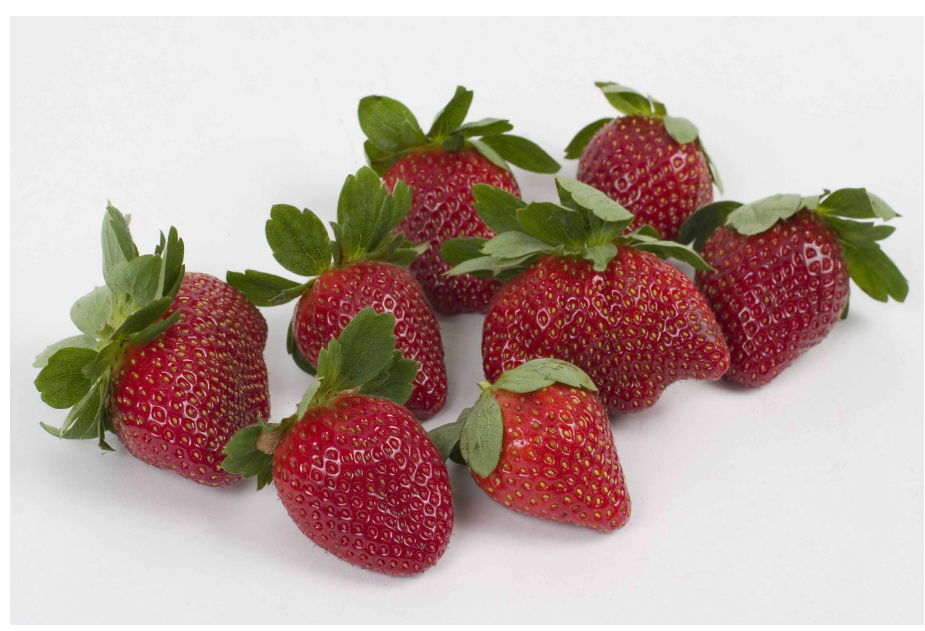

objective of this study is to compare labor costs between Florida and Mexican strawberry industries.

\section{Surveys in Florida and Mexico}

We conducted strawberry industry labor surveys for the Florida 2014/15 season and for the Central Mexico 2013/14 season. The Florida growers survey focused exclusively on labor, including labor costs and productivity, while the Central Mexico strawberry growers survey was more comprehensive, providing an overview of both production

1. This is EDIS document FE1023, a publication of the Food and Resource Economics Department, UF/IFAS Extension. Published December 2017. Visit the EDIS website at http://edis.ifas.ufl.edu.

2. Feng Wu, research assistant scientist, Food and Resource Economics Department, and Zhengfei Guan, assistant professor, Food and Resource Economics Department, UF/IFAS Gulf Coast Research and Education Center, Balm, FL. Melvin Garcia-Nazariega, agro-purchasing manager, Frexport SA de CV, Zamora, Mexico.

The Institute of Food and Agricultural Sciences (IFAS) is an Equal Opportunity Institution authorized to provide research, educational information and other services

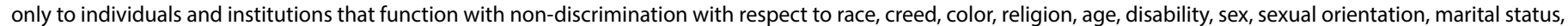

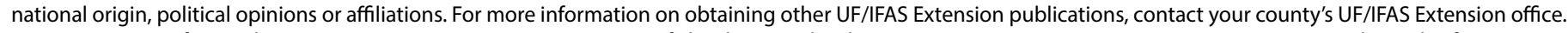
U.S. Department of Agriculture, UF/IFAS Extension Service, University of Florida, IFAS, Florida A \& M University Cooperative Extension Program, and Boards of County Commissioners Cooperating. Nick T. Place, dean for UF/IFAS Extension. 
practices and costs. One section of the survey was dedicated to labor with a focus on costs. Both surveys were completed by in-person interviews. Although labor information collected with these two surveys were for two different seasons (2013/14 vs. 2014/15), the cost comparisons still serve as a reference to highlight the difference in labor costs.

\section{Wage Rates}

In US agriculture, general field work is usually paid by the hour at a low wage rate. In Florida, general field workers are often paid the state minimum wage rate during the survey, which was $\$ 8.05$ per hour in 2015 . Certain specialized work, such as machine operators and tractor drivers, are paid a higher wage, which was $\$ 12$ per hour in 2015 (BLS 2015). Strawberry pickers are usually paid a piece rate, with the rate varying within the season depending on the time of harvest. At the beginning of the strawberry harvest season (November), the fruit yield is lower, so a higher piece rate is paid to meet the minimum wage requirement. On average, pickers are paid $\$ 2.50$ per flat of strawberries (a flat holds 8 pounds of fruit) early in the season. Some growers pay as high as $\$ 3$ per flat. Throughout the season, as fruit yield increases, the time to harvest one flat of strawberries significantly decreases; the piece rate gradually decreases to $\$ 1.75$ per flat of strawberries. Workers in the Mexican strawberry industry are generally paid a lower wage rate. In 2014, the daily wage rates in Central Mexico were 140 to 150 pesos $(\$ 10.10-\$ 10.80)$ for tasks such as bedding, spraying, and runner cutting, and 170 pesos $(\$ 11.50)$ for planting transplants. Mexican piece rates for strawberry pickers varied depending on the market destinations of strawberries. Pickers of fresh strawberries for export markets were paid 15 pesos (\$1.02) per box (4 kilograms or 8.82 pounds), while pickers of strawberries for processing facilities were paid 12 pesos ( $\$ 0.81$ ) per barrel (8 kilograms or 17.6 pounds).

\section{Cost Comparison}

Job tasks requiring intensive seasonal labor input for strawberry production include bedding, planting, runner cutting, spraying, and harvesting. We compare labor costs of these tasks for growers in Florida and Central Mexico (Table 1). Bedding is a series of operations before planting and involves disking, shaping, rolling the beds, applying pre-plant fertilizer, burying irrigation lines, and laying plastic mulch. The labor cost for bedding was $\$ 177$ per acre in Florida for the 2014/15 season, and $\$ 94$ per acre in Central Mexico for the 2013/14 season.
The next step in strawberry production is planting, or plant establishment. Workers gather the plants in buckets or sacks and place the strawberry plants inside the punched holes in the planting beds. In Florida, planting 18,000-20,000 transplants per acre costs $\$ 351$. In Central Mexico, where the transplant population can reach 30,000 per acre, the labor cost was $\$ 86$ per acre.

In midseason, strawberries produce runners whose roots remain attached to the mother plants. These runners need to be cut periodically during the growing season so that the plants have more nutrients for berry production. Usually, three cuttings are needed in Florida. Sometimes growers need to hoe weeds or pull the weeds by hand. On average, these tasks take 117.1 man-hours, costing a total of $\$ 943$ per acre in Florida. Mexican strawberries have a longer production season, lasting from September to June and requiring more runner cuttings. Because no reliable survey data are available for this cost item in Mexico, we assume that Mexican strawberries need five runner cuttings and require $150 \%$ of the amount of Florida cutting time for each cutting due to the longer growing season and higher transplant density. As a result, Mexican growers would spend an average of $\$ 423$ per acre on runner cutting and weeding tasks.

Spraying is an operation in which machine operators drive tractors and spray pesticides to control diseases, insects, and weeds. Florida growers apply chemicals regularly to control disease, with an average frequency of 22 applications over the season, resulting in a labor cost of $\$ 61$ per acre. Spraying labor cost in Mexico was estimated at $\$ 409$ per acre because the task is mostly done manually using high tunnels.

Harvesting is the most labor-intensive operation and constitutes the largest share of total labor expenditures. Florida pickers can pick an average of 11 flats per hour during the peak season, but only about 3 flats per hour at the beginning of the season (November). Weighting the piece rates over time (by monthly yield) and across growers (by acreage), we obtain a season-average piece rate of $\$ 2.30$ per flat for Florida pickers. Assuming an average yield of 3,000 flats per acre (the typical yield level in a normal year), the labor expenditure for harvesting is $\$ 6,900$. The Agrifood and Fisheries Information Service of Mexico (2016) reported that the average Central Mexican strawberry yield was 4,963 flats per acre during 2013-2015. Assuming that $30 \%$ of the strawberries during this period were picked for the export market while others were sold to processing facilities and domestic fresh strawberry markets, the estimated total labor cost for harvesting for the fresh 
export market in Central Mexico was 39,177 pesos per acre, or $\$ 2,830$ per acre at the 2014 average exchange rate.

Altogether, the total of labor costs for producing strawberries in Florida was $\$ 8,432$ per acre compared to 53,173 pesos $(\$ 3,842)$ per acre in Central Mexico (Table 1$)$. To make a fair comparison, we calculated labor costs per flat of strawberries sold to the US market. The labor cost was \$2.81 per flat for Florida strawberries. For Mexican exported strawberries, we need to divide non-harvest labor costs between fresh exported strawberries and non-export strawberries (fresh local plus processing). The survey data show that fresh export strawberries in Central Mexico accounted for about $50 \%$ of total production value, but only $30 \%$ of production volume. We use this as the weight and allocate $50 \%$ of the non-harvest labor cost to fresh export strawberries. Based on the number of flats of fresh strawberries (1489 flats per acre) exported to the United States from Mexico, the per-flat labor cost for strawberries exported to the United States was 18.27 pesos (\$1.27), or about $45 \%$ of the labor cost for Florida strawberries.

\section{Concluding Remarks}

Our survey results show that labor costs significantly more in the Florida strawberry industry than in the Central Mexican strawberry industry, although Central Mexican strawberries require more manual labor due to Mexico's longer picking season. The labor costs for tasks listed in Table 1 were $\$ 8,432$ per acre in Florida compared to 53,173 pesos $(\$ 3,842)$ per acre in Central Mexico. The average labor cost was $\$ 2.81$ per flat for Florida strawberries compared to 18.27 pesos (\$1.27) per flat for Mexican strawberries sold to the US market, which is $45 \%$ of the Florida labor cost.

There are two points that should be noted. First, these cost estimates are only for the tasks covered in Table 1, which are major tasks in strawberry production but are not an exhaustive list. Other tasks excluded from our comparison include crew and general management and post-harvest activities. If these activities were included, the difference would be even larger. Guan, $\mathrm{Wu}$, and Whidden (2017) show that labor costs for crew and general farm management were \$2,224 per acre for Florida strawberries in the 2012/13 season. After adjusting for the wage growth of 5.3\% (OECD 2016), this component would be $\$ 2,342$ per acre for $2014 / 15$. The total labor cost for $2014 / 15$ would be $\$ 10,774$ per acre (based on a yield 3,000 flats per acre). Extrapolating the Mexican labor cost in Table $1(\$ 3,842)$ by the same proportion to account for the crew and general farm management would result in a total labor cost of $\$ 4,895$ per acre for the 2013/14 season. Note that the extrapolation rate used most likely represents the upper bound because the wage difference in Mexico between managers and workers is likely to be less than that in the United States. Further adjusting the labor cost to the 2014/15 season with a $2.4 \%$ wage growth (OECD 2016) to make it comparable to the Florida data results in a total labor cost of $\$ 5,012$ per acre for Mexican strawberries. Compared to the Florida cost estimate, the labor cost for Mexican strawberries was at least $\$ 5,762$ per acre cheaper than that of Florida strawberries.

Second, the exchange rate used in this study was 13.84 pesos per dollar. With the devaluation of the peso against the dollar, it becomes even cheaper to produce strawberries in Mexico. The current exchange rate is around 18 pesos per dollar. This would bring the $\$ 5,012$ per acre down to $\$ 3,853$ per acre, increasing the gap between Florida and Mexican labor costs to $\$ 6,921$ per acre.

In sum, there is a large cost difference in labor between Florida and Mexican strawberry production. This difference is not likely to narrow down in the foreseeable future without a major technological breakthrough, such as the mechanization of strawberry harvesting. Given the wage differences and the dwindling migrant labor supply, it is imperative for the US (and Florida) industry to develop labor-saving technologies and better production systems (Guan et al. 2015).

\section{References}

Agrifood and Fisheries Information Service of Mexico. 2016. Statistical Yearbook of Agricultural Production.http:// www.gob.mx/siap /.

Biswas, T., Z. Guan, and F. Wu. 2017. Competition between Florida and Mexican Fruit and Vegetable Industries. Forthcoming.

Bureau of Labor Statistics (BLS). 2015. 2014 State Occupational Employment and Wage Estimates Florida. Washington, DC: BLS.

Guan, Z., F. Wu, F. Roka, and A. Whidden. 2015. "Agricultural Labor and Immigration Reform." Choices 30(4).

Guan, Z., F. Wu, and A. Whidden. 2017. Florida Strawberry Production Costs and Trends. FE1013. Gainesville, FL: University of Florida, Institute of Food and Agricultural Sciences. http://edis.ifas.ufl.edu/FE1013. 
Hodges, A. 2017. Personal communications on the economic contribution of the Florida strawberry industry. University of Florida, Gainesville, FL.

Organisation for Economic Co-operation and Development (OECD). 2016. Average Annual Wages. https://stats.oecd. org/Index.aspx?DataSetCode=AV_AN_WAGE

Suh, D.H., Z. Guan, and H. Khachatryan. 2017. “The Impact of Mexican Competition on the U.S. Strawberry Industry." International Food and Agribusiness Management Review. Forthcoming.

United States Department of Agriculture, National Agricultural Statistics Service (USDA-NASS). 2016. Quick Stats 2.0. Washington, DC: USDA-NASS. 
Table 1. Labor costs ( $\$ /$ acre) of major tasks in strawberry production

\begin{tabular}{|c|c|c|c|c|}
\hline \multirow[t]{2}{*}{ Items } & \multicolumn{2}{|c|}{ Florida (2014/15) } & \multicolumn{2}{|c|}{ Mexico (2013/14) } \\
\hline & $\$ /$ acre & $\$ /$ flat & $\$ /$ acre & $\$ /$ flat $^{\mathrm{a}}$ \\
\hline Bedding & 177 & 0.06 & 94 & 0.03 \\
\hline Planting & 351 & 0.12 & 86 & 0.03 \\
\hline Cutting, hoeing and weeding & 943 & 0.31 & 423 & 0.14 \\
\hline Spraying & 61 & 0.02 & 409 & 0.14 \\
\hline Harvesting & 6,900 & 2.3 & 2,830 & 0.93 \\
\hline Total & 8,432 & 2.81 & 3,842 & 1.27 \\
\hline
\end{tabular}

